\title{
GENETIC DIVERGENCE AMONG COWPEA GENOTYPES BY MORPHOAGRONOMIC TRAITS ${ }^{1}$
}

\author{
SÉRGIO ROGÉRIO ALVES DE SANTANA ${ }^{2 *}$, JAMILE ERICA DE MEDEIROS ${ }^{2}$, CLODOALDO JOSÉ DA \\ ANUNCIAÇÃO FILHO ${ }^{2}$, JOSÉ WILSON DA SILVA ${ }^{2}$, ANTONIO FÉLIX DA COSTA ${ }^{3}$, GERSON QUIRINO BASTOS ${ }^{2}$
}

\begin{abstract}
Cowpea has great socioeconomic importance, especially in the North and Northeast of Brazil, and its genetic improvement has become increasingly relevant. This study aimed to assess the genetic divergence among cowpea genotypes of the active germplasm bank of the Agronomic Institute of Pernambuco to indicate the most divergent and productive as parents aiming at enriching its breeding program in this institution. The experiment was carried out at the experimental station of Itapirema, Goiana, PE, in a randomized block design with four replications. Thirty genotypes were used in the study, being two of them the controls (Miranda IPA 207 and Paulistinha). The parameters flowering, number of pods per peduncle, number of pods per plant, pod length, ten pod weight, grain index, number of grains in ten pods, hundred-grain weight, grain yield per hectare, plant habit, color of flowers, leaves, pods, and grains, and grain shape were assessed. Genetic divergence was observed among the cowpea genotypes. Pod length and weight, flowering, hundredgrain weight, and the number of pods per plant were the main contributors to genetic divergence. Crosses indicated to enable new gene combinations more favorable for cowpea are Pitiúba $\mathrm{x}$ Cabeçudo, Pitiúba $\mathrm{x}$ Manteiga, and Pitiúba x Costela de Vaca.
\end{abstract}

Keywords: Vigna unguiculata. Germplasm. Variability. Description.

\section{DIVERGÊNCIA GENÉTICA ENTRE GENÓTIPOS DE FEIJÃO-CAUPI POR CARACTERES MORFOAGRONÔMICOS}

\begin{abstract}
RESUMO - O feijão-caupi possui grande importância socioeconômica, principalmente nas regiões Norte/ Nordeste do Brasil. Devido a este fator o melhoramento genético dessa espécie vem se tornando cada vez mais relevante. $\mathrm{O}$ trabalho teve como objetivo avaliar a divergência genética entre genótipos de feijão-caupi do Banco Ativo de Germoplasma do Instituto Agronômico de Pernambuco (IPA), a fim de indicar os mais divergentes e produtivos como genitores de forma a enriquecer o programa de melhoramento da cultura nessa instituição. O ensaio foi conduzido na Estação experimental de Itapirema (IPA), Goiana-PE, em delineamento experimental de blocos casualizados com quatro repetições. Utilizaram-se 30 genótipos sendo duas testemunhas (Miranda IPA 207 e Paulistinha). Foram avaliados: início de floração, número de vagem/ pedúnculo, número de vagem/planta, comprimento médio de vagem, peso de dez vagens, peso dos grãos de dez vagens, índice de grãos, número de grãos em dez vagens, peso de cem grãos, rendimento de grãos/hectare, porte, cor da flor, da folha, da vagem e do grão e a forma do grão. Existe divergência genética entre os genótipos de feijão-caupi avaliados. As características peso de vagem, início da floração, comprimento da vagem, peso de cem grãos e número de vagens por planta foram as que mais contribuíram para a divergência genética. Os cruzamentos indicados para viabilizar novas combinações gênicas mais favoráveis são: Pitiúba $\mathrm{x}$ Cabeçudo, Pitiúba x Manteiga e Pitiúba x Costela de Vaca.
\end{abstract}

Palavras-chave: Vigna unguiculata. Germoplasma. Variabilidade. Caracterização.

\footnotetext{
${ }^{*}$ Corresponding author

${ }^{1}$ Received for publication in 01/15/2019; accepted in 07/08/2019

Paper extracted from the masters dissertation of the first author.

${ }^{2}$ Department of Agronomy, Universidade Federal Rural de Pernambuco, Recife, PE, Brazil; sergiorogerio1@hotmail.com - ORCID: 00000002-2259-0772, jamileerica@gmail.com - ORCID: 0000-0001-9123-0351, cjoseufrpe@hotmail.com - ORCID: 0000-0001-9197-940X, jwsamaral@hotmail.com - ORCID: 0000-0002-0217-7665, bastosgq@hotmail.com - ORCID: 0000-0002-7418-7475.

${ }^{3}$ Instituto Agronômico de Pernambuco, Recife, PE, Brazil; felix.antonio@ipa.br - ORCID: 0000-0001-9866-3504.
} 


\section{INTRODUCTION}

Cowpea [Vigna unguiculata (L.) Walp.] is one of the most important crops for the Northeast region of Brazil, being considered the main subsistence crop of rural populations and grown by small and medium producers of this region and large producers in the Midwest region, contributing to employment and income generation (XAVIER et al., 2005; ROCHA et al., 2009; BEZERRA et al., 2010). It is an essential source of protein and essential amino acids, besides having dietary fibers, constituting a basic component for the feeding of populations of this region (CORREA et al., 2012).

Brazil is among the three world's largest cowpea producers, with an estimated production of 841.3 thousand tons for the 2017/2018 agricultural season (CONAB, 2018). However, the large production of this grain contrasts with its low productivity, which generates a permanent supply deficit in the Northeast region. The mean Brazilian productivity is around $520 \mathrm{~kg} \mathrm{ha}^{-1}$ (CONAB, 2018).

Some advances in cowpea cultivation can be mentioned because of genetic improvement, such as the development of earlier and uniform cultivars, resistance and tolerance to biotic and abiotic stresses, semi-erect habit with pod insertion above the foliage and uniformity of pod maturation, higher stability and adaptability, among others (BARROSO NETO et al., 2017).

Due to the great importance that this crop has in Brazil, especially for Northeast region, studies need to be carried out to assess the genetic divergence, aiming at the selection of more divergent genotypes, more adapted, and with higher production potential (TORRES FILHO et al., 2018). The assessment of the genetic diversity of populations allows the knowledge of the best hybrid combinations with higher heterotic effect and heterozygosis (PASSOS et al., 2007).

According to Barbieri et al. (2005), the higher the divergence between parents is, the higher the resulting variability in the segregating population and the higher the probability of regrouping alleles into new favorable combinations. Allard (1960) states that the best way to obtain superior genotypes is to use parents with a broad genetic diversity for morphoagronomic traits of agricultural interest.

The information obtained from the characterization and assessment of materials from germplasm banks is useful tools for breeders. Germplasm characterization has been performed by means of several morphoagronomic traits, and several multivariate techniques have been used, such as principal component analysis (BERTINI et al., 2010), canonical variable analysis (BERTINI et al., 2009), and clustering methods (SANTOS et al., 2014), whose application depends on the use of a previously estimated dissimilarity measure (OLIVEIRA et al., 2003).
Among the multivariate techniques, clustering methods such as Tocher (RAO, 1952) and UPGMA (mean bonding between groups), based on the generalized Mahalanobis distance $\left(\mathrm{D}^{2}\right)$, standing out, being widely used by researchers to estimate the genetic divergence in cowpea (OLIVEIRA et al., 2003; PASSOS et al., 2007; BERTINI et al., 2009; ALMEIDA et al., 2011; SANTOS et al., 2014, TORRES FILHO et al., 2018).

This study aimed to assess the genetic divergence among cowpea genotypes of the active germplasm bank of the Agronomic Institute of Pernambuco to indicate the most divergent and productive as parents aiming at enriching its breeding program in this institution.

\section{MATERIAL AND METHODS}

Thirty erect and semi-erect cowpea genotypes, obtained from BAG-IPA from different localities of the Northeast region, composed the following treatments: Rasga Letra, Cabeçudo, Pitiúba, Manteiga, Coruja, Canapu PE, Paulistinha, Epace 10, Maravilha, Miranda IPA 207, BRS Xiquexique, BRS Tumucumaque, BRS Guariba, Sempre Verde Verdadeiro, Bastião, Sempre Verde Salgueiro, Bastiãozinho, Patativa, Chico Modesto 2, Rouxinol, Esperança, Portalegre RN1, Canapuzinho, Safrinha 1, Pele de Moça, CNC 0434, BR 10 Piauí, Bajão, Costela de Vaca, and BRS Novaera.

The experiment was conducted at the Experimental Station of Itapirema-IPA, located at BR101 Norte, km 53, Goiana, PE, from June to October 2016. The soil where the test was carried out is classified as a silty clay Spodosol (EMBRAPA, 1997). Soil tillage was carried out 15 days before planting and consisted of plowing and harrowing.

The statistical design was a randomized block design with four replications. The experimental plot consisted of a row of $3.0 \mathrm{~m}$ in length, with a spacing of $0.80 \mathrm{~m}$ between rows and $0.25 \mathrm{~m}$ between plants, totaling 12 pits per row. Plot area had $2.4 \mathrm{~m}^{2}$, which was also its useful area. Sowing was carried out by placing three seeds per pit with a depth of about 5 to $10 \mathrm{~cm}$, together with the recommended base fertilization for the state of Pernambuco. Thinning was not carried out, and the cultivation was performed under rainfed conditions. Two manual weedings were carried out to control weeds, the first one at 15 days and the second at 30 days after seedling emergence. There was no need for phytosanitary control.

Descriptors were based on the list proposed by the Bioversity International (2007), with adaptations related to pod and seed integument colors, with the need to create coloring intensity levels. Six plants were assessed per plot, considering their phenological stage for each of the assessed descriptors. 
Quantitative descriptors consisted of beginning of flowering (BF) - number of days from sowing to beginning of flowering; pod length (PL) mean length of ten randomly taken dry pods; number of pods per peduncle (NPPE) - number of pods divided by the number of peduncles; number of pods per plant (NPP) - number of pods in six plants; pod weight $(\mathrm{PW})$ - weight of ten randomly harvested pods from six selected plants; ten-pod grain weight (PGW) - grain weight of ten assessed pods; grain index (GI) - ratio between seed weight from ten pods and weight of ten pods; number of grains per pod (NGP) - mean number of grains from ten dried pods; hundred-grain weight $(\mathrm{HGW})$ - mean weight of three 100-grain replications with approximately $13 \%$ moisture; and productivity (PROD) - total grain production per hectare.

Qualitative descriptors consisted of plant habit - classified as erect, semi-erect, semi-prostrate, and prostrate; leaf color - classified as dark green (DG), intermediate green (IG), and light green (LG); flower color - white (W) and purple (P); pod color color of the dried pod, classified as yellow (Y), light yellow (LY), light brown (LB), and red $=(\mathrm{R})$; grain color - color of grains when dry; grain shape reniform, globose, rounded, ovoid, or rhomboid. Two harvests were performed manually, with an interval of 15 days between them.

The obtained data were submitted to analysis of variance, from which the means, variance matrix, and residual covariance were obtained. Means were compared by the test at $5 \%$ probability for all analyzed quantitative descriptors. Cluster analysis was performed by the Tocher agglomerative method and UPGMA hierarchical method (mean bonding between groups) from the generalized Mahalanobis distance $\left(D^{2}\right)$ (MAHALANOBIS, 1936). Mojena (1977) method was used to determine the cut-off point in the dendrogram, which is a procedure based on the relative size of dendrogram merge levels (distances). This method is based on selecting the number of groups at stage $\mathrm{j}$ that first satisfies the following inequality: $\alpha \mathrm{j}>\theta_{\mathrm{k}}$, where $\alpha \mathrm{j}$ is the value of the merge level corresponding to stage $\mathrm{j}(\mathrm{j}=1,2, \ldots$ $\mathrm{g}-1)$ and $\theta_{\mathrm{k}}$ is the reference cut-off value, expressed as $\theta_{\mathrm{k}}=+\mathrm{k} \sigma_{\alpha}$, where $\sigma_{\alpha}$ represents unbiased estimates of the mean and standard deviation of $\alpha$ values and $\mathrm{k}$ is a constant. A $\mathrm{k}=1.25$ was adopted to define the number of groups, according to Milligan and Cooper (1985). All statistical analyses were performed using the software GENES (CRUZ, 2015).

\section{RESULTS AND DISCUSSION}

Qualitative traits presented variability between genotypes (Table 1), standing out grain color, a fundamental trait for seed identity and quality standards governed by the National Cultivar Registry (RCN), responsible for enabling cultivars and species for the production and commercialization of seeds and seedlings in Brazil.

In Brazil, there is a preference for lightcolored grains without halo and with a small, lightcolored hilum and hilum ring (FREIRE FILHO et al., 2011). These traits were found in $20 \%$ of the assessed genotypes, but the predominant grain coloration was brown, found in $70 \%$ of the assessed genotypes.

About $10 \%$ of the genotypes presented an erect habit, which is a desired characteristic for mechanized harvesting, while the others presented a semi-erect size. Grain shape varied from rounded $(3.33 \%)$ to ovoid $(46.66 \%)$. Reniform, ovoid, and rhomboid shapes predominate in the commercialization of packed grains, all of them without sharp edges, thus reflecting consumer preferences (FREIRE FILHO et al., 2011). The results show the existence of genetic variability in cowpea germplasm for the assessed traits.

The coefficient of variation for the ten traits ranged from $4.39 \%$ for grain index to $23.65 \%$ for grain yield, indicating overall good experimental accuracy (Table 2). Treatments presented significant differences by the F-test $(p<0.01)$ for all the studied traits. The mean number of days to begin flowering was 46.53 days, with a range from 40.25 to 58.75 days. These results are consistent with those found by Silva et al. (2013) who assessed different cowpea cultivars for green grain production in Serra Talhada, $\mathrm{PE}$, and obtained a mean between 43.50 and 55.25 days. 
Table 1. Origin and traits of genotypes from the germplasm bank of the Agronomic Institute of Pernambuco used in the experiment.

\begin{tabular}{|c|c|c|c|c|c|c|c|}
\hline \multirow[b]{2}{*}{ Name } & \multirow[b]{2}{*}{ Origen } & \multicolumn{6}{|c|}{ Botanical traits } \\
\hline & & Habit & Leaf color & $\begin{array}{l}\text { Flower } \\
\text { color }\end{array}$ & Pod color & Grain color & Grain shape \\
\hline Rasga Letra & $\mathrm{PE}$ & $\mathrm{SE}$ & LG & $\mathrm{P}$ & LY & B & $\mathrm{OV}$ \\
\hline Cabeçudo & PB & SE & IG & $\mathrm{P}$ & Y & $\mathrm{B}$ & LO \\
\hline Pitiúba & PI & SE & IG & $\mathrm{P}$ & LY & B & $\mathrm{RE}$ \\
\hline Manteiga & PE & SE & IG & $\mathrm{P}$ & $\mathrm{Y}$ & B & OV \\
\hline Coruja & $\mathrm{PE}$ & SE & IG & $\mathrm{P}$ & $\mathrm{Y}$ & B & $\mathrm{RH}$ \\
\hline Canapu PE & PE & SE & IG & $\mathrm{P}$ & Y & B & RH \\
\hline Paulistinha & PI & SE & IG & $\mathrm{P}$ & $\mathrm{Y}$ & B & RH \\
\hline Epace 10 & $\mathrm{PE}$ & SE & DG & $\mathrm{P}$ & Y & B & RH \\
\hline Maravilha & PB & SE & IG & $\mathrm{P}$ & LY & B & RH \\
\hline Miranda IPA 207 & PE & SE & IG & $\mathrm{P}$ & $\mathrm{Y}$ & B & OV \\
\hline BRS Xiquexique & PI & SE & IG & W & Y & W & OV \\
\hline BRS Tumucumaque & PI & ER & DG & W & LB & $\mathrm{C}$ & $\mathrm{RE}$ \\
\hline BRS Guariba & PI & ER & DG & W & LB & $\mathrm{C}$ & $\mathrm{RE}$ \\
\hline Sempre Verde V. & PE & SE & IG & $\mathrm{P}$ & LY & B & $\mathrm{RE}$ \\
\hline Bastião & PE & SE & IG & $\mathrm{P}$ & Y & B & RH \\
\hline Sempre Verde S. & PE & SE & IG & $\mathrm{P}$ & $\mathrm{Y}$ & B & $\mathrm{RE}$ \\
\hline Bastiãozinho & PE & SE & IG & $\mathrm{P}$ & $\mathrm{Y}$ & B & OV \\
\hline Bajão & PE & SE & IG & W & LB & B & OV \\
\hline Patativa & PI & SE & IG & $\mathrm{P}$ & $\mathrm{Y}$ & B & OV \\
\hline Chico Modesto 2 & PE & $\mathrm{SE}$ & IG & W & $\mathrm{Y}$ & $\mathrm{C}$ & OV \\
\hline BRS Novaera & PI & SE & IG & W & $\mathrm{Y}$ & W & $\mathrm{RE}$ \\
\hline Rouxinol & PE & $\mathrm{SE}$ & DG & W & LB & M & OV \\
\hline Esperança & PE & SE & IG & $\mathrm{P}$ & LB & $\mathrm{R}$ & OV \\
\hline Portalegre RN 1 & $\mathrm{RN}$ & SE & IG & $\mathrm{P}$ & Y & B & OV \\
\hline Canapuzinho & PE & SE & IG & $\mathrm{P}$ & $\mathrm{Y}$ & B & OV \\
\hline Safrinha 1 & PE & SE & IG & W & LB & $\mathrm{C}$ & $\mathrm{RE}$ \\
\hline Costela de Vaca & PE & SE & IG & $\mathrm{P}$ & $\mathrm{R}$ & B & $\mathrm{RE}$ \\
\hline Pele de Moça & PE & $\mathrm{SE}$ & IG & $P$ & $\mathrm{Y}$ & B & OV \\
\hline CNC 0434 & PI & SE & IG & $\mathrm{P}$ & LY & $\mathrm{C}$ & RO \\
\hline BR 10 Piauí & PI & ER & IG & $\mathrm{P}$ & $\mathrm{Y}$ & B & OV \\
\hline
\end{tabular}

Origin: Paraíba (PB), Pernambuco (PE), Piauí (PI), and Rio Grande do Norte (RN); habit: erect (ER), semi-erect (SE), prostrate (PR), and semi-prostrate (SP); leaf color: dark green (DG), intermediate green (IG), and light green (LG); flower color: white (W) and purple (P); pod color: yellow (Y), light yellow (LY), light brown (LB), red (R); grain color: brown (B), cream $(\mathrm{C})$, white $(\mathrm{W})$, red $(\mathrm{R})$, mixed $(\mathrm{M})$; grain shape: ovoid (OV), long (LO), rhomboid (RH), rounded (RO), reniform (RE). 
Table 2. Summary of analysis of variance, mean squares, and coefficients of variation of the experimental error (CV) for traits assessed in 30 cowpea genotypes in Goiana, PE, 2017.

\begin{tabular}{cccccccccccc}
\hline SV & DF & \multicolumn{10}{c}{ Mean squares } \\
\cline { 2 - 11 } & $\begin{array}{c}\text { BF } \\
\text { (days) }\end{array}$ & NPPE & NPP & $\begin{array}{c}\text { PL } \\
(\mathrm{cm})\end{array}$ & $\begin{array}{c}\text { PGW } \\
(\mathrm{g})\end{array}$ & $\begin{array}{c}\text { PGV } \\
(\mathrm{g})\end{array}$ & $\begin{array}{c}\text { GI } \\
(\%)\end{array}$ & $\begin{array}{c}\text { NGP } \\
(\mathrm{g})\end{array}$ & $\begin{array}{c}\text { REW } \\
\left.(\mathrm{kg} \mathrm{ha})^{-1}\right)\end{array}$ \\
\hline Blocks & 3 & 10.16 & 0.035 & 3.42 & 3.15 & 94.90 & 40.52 & 3.64 & 1.52 & 4.43 & 25321 \\
Genotypes & 29 & $74.6^{* *}$ & $0.11^{* *}$ & $12.4^{* *}$ & $17.1^{* *}$ & $131.8^{* *}$ & $74.1^{* *}$ & $61.3^{* *}$ & $7.1^{* *}$ & $26.5^{* *}$ & $421111^{* *}$ \\
Residual & 87 & 5.65 & 0.023 & 1.79 & 2.74 & 30.01 & 15.69 & 11.81 & 2.03 & 5.04 & 66488 \\
\hline Mean & & 46.53 & 1.16 & 6.14 & 20.28 & 38.00 & 29.66 & 78.29 & 12.32 & 24.47 & 1090 \\
CV (\%) & 5.11 & 13.14 & 21.75 & 8.16 & 14.42 & 13.36 & 4.39 & 11.57 & 9.17 & 23.65 \\
\hline
\end{tabular}

${ }^{1} \mathrm{BF}$ - beginning of flowering; NPPE - number of pods per peduncle; NPP - number of pods per plant; PL - pod length; PW - ten pod weight; PGW - ten-pod grain weight; GI - grain index; NGP - number of grains per pod; HGW - hundredgrain weight; and PROD - grain productivity. ${ }^{* *}$ Significant at $1 \%$ probability level by the F-test.

Grain productivity had an overall mean of $1,090 \mathrm{~kg} \mathrm{ha}^{-1}$, which is similar to the results found by Matos Filho et al. (2009), who assessed 3 strains and 348 progenies from $\mathrm{F}_{2}$ and $\mathrm{F}_{3}$ generation of backcrosses P1 x P2 and P1 x P3, with different growth habits, and Lopes et al., (2001), who assessed 28 strains and two controls that stood out in a selection for integument color, grain size, and resistance to viruses, and found means of 1,007 and $1,049 \mathrm{~kg}$ $\mathrm{ha}^{-1}$, respectively. However, this result was lower when compared to the means found by Teixeira et al. (2010), who assessed the agronomic performance of eight cowpea varieties recommended for cultivation in the North and Northeast regions, and Bezerra et al.
(2008), who assessed morphology and grain production in five cowpea strains sown at different population densities, and found productivity means of 1,307 and $1,705 \mathrm{~kg} \mathrm{ha}^{-1}$, respectively.

This low mean productivity may be related to the low precipitation during the experiment when only $181.0 \mathrm{~mm}$ were observed in the area, most of them in July and very little in August, September, and October (Table 3). This precipitation is below the minimum crop requirement of around $300 \mathrm{~mm}$, and water availability is one of the environmental factors that most influence plant productivity, especially in semiarid regions (BASTOS et al., 2012).

Table 3. Precipitation data from Experimental Station of Itapirema, Goiana, PE, 2017.

\begin{tabular}{ccc}
\hline Month & Precipitation $(\mathrm{mm})$ & Number of rainy days \\
\hline June $^{1}$ & 17.1 & 2 \\
July & 68.3 & 19 \\
August & 46.1 & 13 \\
September & 47.5 & 12 \\
October $^{2}$ & 2.00 & 4 \\
\hline Total & 181.0 & 50 \\
\hline${ }^{1}$ Precipitation volume for four days; ${ }^{2}$ Precipitation volume for 12 days (the period
\end{tabular}
between sowing and harvesting).

In addition, a decrease in precipitation was observed in August and September, with only 46.1 and $47.5 \mathrm{~mm}$, respectively, when genotypes started reproductive stage, which contributed to a decrease in cowpea productivity since it is one of the stages in which crop is more sensitive to water deficit
(BEZERRA et al., 2003).

The mean values of the ten traits studied in six plants for each treatment, overall means, and results of the Scott and Knott test at 5\% probability are shown in Table 4. 
Table 4. Mean values resulting from the Scott-Knott test in the assessed variables: beginning of flowering (BF), number of pods per peduncle (NPPE), number of pods per plant (NPP), pod length (PL), ten-pod weight (PW), ten-pod grain weight (PGW), grain index (GI), number of grains per pod (NGP), hundred-grain weight (HGW), and grain productivity per hectare (PROD) obtained from the assessment of 30 cowpea genotypes, Goiana, PE, 2017.

\begin{tabular}{|c|c|c|c|c|c|c|c|c|c|c|}
\hline Genotype & $\begin{array}{c}\mathrm{BF} \\
(\text { days })\end{array}$ & NPPE & NPP & $\begin{array}{l}\mathrm{PL} \\
(\mathrm{cm})\end{array}$ & $\begin{array}{l}\text { PW } \\
(\mathrm{g})\end{array}$ & $\begin{array}{c}\text { PGW } \\
(\mathrm{g})\end{array}$ & $\begin{array}{l}\text { GI } \\
(\%)\end{array}$ & $\begin{array}{l}\text { NGP } \\
\text { (unit) }\end{array}$ & $\begin{array}{c}\mathrm{HGW} \\
(\mathrm{g})\end{array}$ & $\begin{array}{c}\text { PROD } \\
\left(\mathrm{kg} \mathrm{ha}^{-1}\right)\end{array}$ \\
\hline Rasga Letra & $45.7 \mathrm{E}$ & $1.2 \mathrm{C}$ & $7.3 \mathrm{~B}$ & $20.6 \mathrm{~B}$ & $37.8 \mathrm{C}$ & $29.6 \mathrm{~A}$ & $78.5 \mathrm{~A}$ & $12.97 \mathrm{~A}$ & $23.5 \mathrm{~B}$ & $1356.4 \mathrm{~A}$ \\
\hline Cabeçudo & $51.5 \mathrm{C}$ & $1.1 \mathrm{C}$ & $5.9 \mathrm{~B}$ & $15.4 \mathrm{D}$ & $38.8 \mathrm{~B}$ & $31.0 \mathrm{~A}$ & $80.0 \mathrm{~A}$ & $11.8 \mathrm{~A}$ & $26.5 \mathrm{~A}$ & $1468.2 \mathrm{~A}$ \\
\hline Pitiúba & $47.5 \mathrm{D}$ & $1.1 \mathrm{C}$ & $5.1 \mathrm{C}$ & $21.2 \mathrm{~B}$ & $35.2 \mathrm{C}$ & $26.9 \mathrm{~B}$ & $77.6 \mathrm{~A}$ & $14.3 \mathrm{~A}$ & $19.3 \mathrm{C}$ & $1633.5 \mathrm{~A}$ \\
\hline Manteiga & 49.7C & $1.0 \mathrm{D}$ & $5.5 \mathrm{C}$ & $17.7 \mathrm{D}$ & $52.5 \mathrm{~A}$ & $38.5 \mathrm{~A}$ & $73.5 \mathrm{~B}$ & $13.2 \mathrm{~A}$ & $29.2 \mathrm{~A}$ & $1430.9 \mathrm{~A}$ \\
\hline Coruja & $50.2 \mathrm{C}$ & $1.0 \mathrm{D}$ & $5.8 \mathrm{~B}$ & $19.8 \mathrm{C}$ & $38.8 \mathrm{~B}$ & $30.5 \mathrm{~A}$ & 78.7A & $12.1 \mathrm{~A}$ & $24.9 \mathrm{~A}$ & $1501.9 \mathrm{~A}$ \\
\hline Canapu PE & $42.2 \mathrm{~F}$ & $1.3 \mathrm{~B}$ & $6.5 \mathrm{~B}$ & $18.7 \mathrm{C}$ & $36.1 \mathrm{C}$ & $29.7 \mathrm{~A}$ & $82.2 \mathrm{~A}$ & $11.9 \mathrm{~A}$ & $25.1 \mathrm{~A}$ & $1360.9 \mathrm{~A}$ \\
\hline Paulistinha & $43.2 \mathrm{E}$ & $1.2 \mathrm{C}$ & $6.1 \mathrm{~B}$ & $20.5 \mathrm{~B}$ & $40.0 \mathrm{~B}$ & $32.4 \mathrm{~A}$ & $81.1 \mathrm{~A}$ & $12.0 \mathrm{~A}$ & $27.3 \mathrm{~A}$ & $1309.5 \mathrm{~A}$ \\
\hline Epace 10 & $45.5 \mathrm{E}$ & $1.1 \mathrm{C}$ & $6.5 \mathrm{~B}$ & $21.5 \mathrm{~B}$ & $37.9 \mathrm{C}$ & $31.1 \mathrm{~A}$ & $82.1 \mathrm{~A}$ & $13.8 \mathrm{~A}$ & $22.8 \mathrm{~B}$ & $1458.0 \mathrm{~A}$ \\
\hline Maravilha & $47.2 \mathrm{D}$ & $1.0 \mathrm{D}$ & $5.5 \mathrm{C}$ & $21.2 \mathrm{~B}$ & $40.4 \mathrm{~B}$ & $32.4 \mathrm{~A}$ & $80.2 \mathrm{~A}$ & $12.9 \mathrm{~A}$ & $25.2 \mathrm{~A}$ & 601.3B \\
\hline Miranda IPA 207 & $41.5 \mathrm{~F}$ & $1.0 \mathrm{D}$ & $4.5 \mathrm{C}$ & $22.2 \mathrm{~B}$ & $42.2 \mathrm{~B}$ & $32.9 \mathrm{~A}$ & $78.0 \mathrm{~A}$ & $13.0 \mathrm{~A}$ & $26.0 \mathrm{~A}$ & $1237.5 \mathrm{~A}$ \\
\hline BRS Xiquexique & $47.0 \mathrm{D}$ & $1.2 \mathrm{C}$ & $8.2 \mathrm{~B}$ & $19.8 \mathrm{C}$ & $30.2 \mathrm{D}$ & $24.8 \mathrm{~B}$ & $81.9 \mathrm{~A}$ & $13.1 \mathrm{~A}$ & $19.3 \mathrm{C}$ & $815.9 \mathrm{~B}$ \\
\hline BRS Tumucumaque & $40.2 \mathrm{~F}$ & $1.5 \mathrm{~A}$ & $6.5 \mathrm{~B}$ & $20.5 \mathrm{~B}$ & $32.3 \mathrm{D}$ & 26.9B & $83.7 \mathrm{~A}$ & $10.2 \mathrm{~B}$ & $24.4 \mathrm{~A}$ & $1287.5 \mathrm{~A}$ \\
\hline BRS Guariba & $44.0 \mathrm{E}$ & $1.6 \mathrm{~A}$ & $8.1 \mathrm{~B}$ & $20.2 B$ & $32.9 \mathrm{D}$ & $27.2 \mathrm{~B}$ & $82.9 \mathrm{~A}$ & $11.1 \mathrm{~B}$ & $24.6 \mathrm{~A}$ & $782.8 \mathrm{~B}$ \\
\hline Sempre V. V. & $48.7 \mathrm{D}$ & $1.0 \mathrm{D}$ & $4.3 \mathrm{C}$ & $21.3 \mathrm{~B}$ & $42.8 \mathrm{~B}$ & $32.6 \mathrm{~A}$ & $76.1 \mathrm{~B}$ & $13.5 \mathrm{~A}$ & $24.6 \mathrm{~A}$ & $685.4 \mathrm{~B}$ \\
\hline Bastião & $48.5 \mathrm{D}$ & $1.1 \mathrm{C}$ & $6.8 \mathrm{~B}$ & $20.7 \mathrm{~B}$ & $44.3 \mathrm{~B}$ & $35.5 \mathrm{~A}$ & $80.2 \mathrm{~A}$ & $14.3 \mathrm{~A}$ & $25.3 \mathrm{~A}$ & $1411.7 \mathrm{~A}$ \\
\hline Sempre V. S. & $44.0 \mathrm{E}$ & 1.1D & $5.2 \mathrm{C}$ & $20.5 \mathrm{~B}$ & $36.4 \mathrm{C}$ & $29.8 \mathrm{~A}$ & $82.6 \mathrm{~A}$ & $12.5 \mathrm{~A}$ & $24.8 \mathrm{~A}$ & $1096.0 \mathrm{~A}$ \\
\hline Bastiãozinho & $47.8 \mathrm{D}$ & $0.9 \mathrm{D}$ & $4.0 \mathrm{C}$ & 21.1B & 42.7B & $34.4 \mathrm{~A}$ & $80.5 \mathrm{~A}$ & $13.62 \mathrm{~A}$ & $25.2 \mathrm{~A}$ & $1134.6 \mathrm{~A}$ \\
\hline Bajão & $54.0 \mathrm{~B}$ & $1.0 \mathrm{D}$ & $4.5 \mathrm{C}$ & $25.9 \mathrm{~A}$ & $45.5 \mathrm{~B}$ & $30.3 \mathrm{~A}$ & $66.9 \mathrm{C}$ & $13.2 \mathrm{~A}$ & $23.6 \mathrm{~B}$ & $1069.1 \mathrm{~A}$ \\
\hline Patativa & $41.2 \mathrm{~F}$ & $1.3 \mathrm{~B}$ & $6.4 \mathrm{~B}$ & $18.6 \mathrm{C}$ & $30.3 \mathrm{D}$ & $23.3 \mathrm{~B}$ & $76.8 \mathrm{~B}$ & 10.1B & 22.9B & $612.5 \mathrm{~B}$ \\
\hline Chico Modesto2 & $52.5 \mathrm{~B}$ & $1.2 \mathrm{C}$ & $4.9 \mathrm{C}$ & $20.5 \mathrm{~B}$ & $31.1 \mathrm{D}$ & $22.1 \mathrm{~B}$ & $71.5 \mathrm{C}$ & $11.0 \mathrm{~B}$ & $19.7 \mathrm{C}$ & $1306.6 \mathrm{~A}$ \\
\hline BRS Novaera & $44.8 \mathrm{E}$ & $1.4 \mathrm{~B}$ & $13.5 \mathrm{~A}$ & $16.9 \mathrm{D}$ & 27.7D & $20.1 \mathrm{~B}$ & $72.3 \mathrm{C}$ & $8.3 \mathrm{~B}$ & $27.9 \mathrm{~A}$ & $581.6 \mathrm{~B}$ \\
\hline Rouxinol & $39.8 \mathrm{~F}$ & $1.2 \mathrm{C}$ & $7.7 \mathrm{~B}$ & $19.8 \mathrm{C}$ & $37.5 \mathrm{C}$ & $30.6 \mathrm{~A}$ & $81.4 \mathrm{~A}$ & $12.1 \mathrm{~A}$ & $26.4 \mathrm{~A}$ & $1275.0 \mathrm{~A}$ \\
\hline Esperança & $47.8 \mathrm{D}$ & $0.9 \mathrm{D}$ & $6.1 \mathrm{~B}$ & $19.3 \mathrm{C}$ & $37.4 \mathrm{C}$ & $28.7 \mathrm{~A}$ & $77.0 \mathrm{~B}$ & $12.8 \mathrm{~A}$ & $22.6 \mathrm{~B}$ & $953.7 \mathrm{~B}$ \\
\hline Portalegre RN 1 & $51.2 \mathrm{C}$ & $1.1 \mathrm{C}$ & $5.4 \mathrm{C}$ & 21.9B & $39.3 \mathrm{~B}$ & $30.0 \mathrm{~A}$ & $76.5 \mathrm{~B}$ & 11.4B & $26.8 \mathrm{~A}$ & 1297.1A \\
\hline Canapuzinho & $44.2 \mathrm{E}$ & $0.9 \mathrm{D}$ & $6.1 \mathrm{~B}$ & $18.7 \mathrm{C}$ & 39.9B & $31.9 \mathrm{~A}$ & $80.1 \mathrm{~A}$ & $12.7 \mathrm{~A}$ & $25.6 \mathrm{~A}$ & $1147.2 \mathrm{~A}$ \\
\hline Safrinha 1 & $43.5 \mathrm{E}$ & $1.2 \mathrm{C}$ & $6.3 \mathrm{~B}$ & $19.6 \mathrm{C}$ & $30.6 \mathrm{D}$ & $24.5 \mathrm{~B}$ & $79.9 \mathrm{~A}$ & $10.6 \mathrm{~B}$ & $23.3 \mathrm{~B}$ & $694.8 \mathrm{~B}$ \\
\hline Costela de Vaca & $58.8 \mathrm{~A}$ & $1.2 \mathrm{C}$ & $4.6 \mathrm{C}$ & $24.9 \mathrm{~A}$ & $49.4 \mathrm{~A}$ & $36.8 \mathrm{~A}$ & $74.0 \mathrm{~B}$ & $13.3 \mathrm{~A}$ & $28.2 \mathrm{~A}$ & $1081.4 \mathrm{~A}$ \\
\hline Pele de Moça & $43.0 \mathrm{E}$ & $1.2 \mathrm{C}$ & $5.1 \mathrm{C}$ & $19.8 \mathrm{C}$ & $40.6 \mathrm{~B}$ & $32.9 \mathrm{~A}$ & $81.3 \mathrm{~A}$ & $12.8 \mathrm{~A}$ & $26.0 \mathrm{~A}$ & $621.6 \mathrm{~B}$ \\
\hline $\mathrm{CNC} 0434$ & $45.0 \mathrm{E}$ & $1.1 \mathrm{C}$ & $6.5 \mathrm{~B}$ & $17.9 \mathrm{D}$ & $32.6 \mathrm{D}$ & $24.3 \mathrm{~B}$ & $74.3 \mathrm{~B}$ & $12.6 \mathrm{~A}$ & $19.5 \mathrm{C}$ & 651.6B \\
\hline BR 10 Piauí & $45.5 \mathrm{E}$ & $1.2 \mathrm{C}$ & $5.2 \mathrm{C}$ & $21.5 \mathrm{~B}$ & $36.4 \mathrm{C}$ & $27.8 \mathrm{~B}$ & 76.4B & $12.3 \mathrm{~B}$ & $23.3 \mathrm{~B}$ & 841.3B \\
\hline Overall mean & 46.5 & 1.2 & 6.2 & 20.3 & 38.0 & 29.7 & 78.3 & 12.3 & 24.5 & 1090.2 \\
\hline
\end{tabular}

Means followed by the same letters in the column do not differ from each other by the Scott-Knott (1974) clustering method at $5 \%$ probability level.

The mean values of the number of pods per plant ranged from 4.0 to 13.5 for the genotypes Bastiãozinho and BRS Novaera, respectively. The mean values for pod length ranged from 15.3 and $25.9 \mathrm{~cm}$ for the genotypes Cabeçudo and Bajão, respectively. The genotype Manteiga had the best means for pod weight $(52.5 \mathrm{~g})$, grain weight per pod (38.5 g), and hundred-grain weight (29.2 g), which were higher than the controls Paulistinha and Miranda IPA 207. The overall mean of the number of grains per pod was 12.3 , and only $30 \%$ of the genotypes were superior to the control of the highest value (Miranda IPA 207), standing out Pitiúba (14.3 grains per pod) and Bastião (14.3 grains per pod).

The clustering method proposed by Tocher, cited by Rao (1952) allowed the division of the 30 genotypes into three distinct groups from the generalized distances of Mahalanobis (1936) (Table 5). 
Table 5. Clustering of 30 cowpea genotypes by the Tocher optimization method as a function of the generalized Mahalanobis distance. Goiana, PE, 2017.

\begin{tabular}{|c|c|c|c|}
\hline Group & Genotype & Number of genotypes & Mean distances \\
\hline I & $\begin{array}{l}\text { Rasga Letra, Cabeçudo, Pitiúba, Manteiga, Coruja, Canapu } \\
\text { PE, Paulistinha, Epace 10, Maravilha, Miranda IPA 207, BRS } \\
\text { Xiquexique, BRS Tumucumaque, BRS Guariba, Sempre } \\
\text { Verde Verdadeiro, Bastião, Sempre Verde Salgueiro, } \\
\text { Bastiãozinho, Patativa, Chico Modesto 2, Rouxinol, } \\
\text { Esperança, Portalegre RN1, Canapuzinho, Safrinha 1, Pele de } \\
\text { Moça, CNC 0434, and BR } 10 \text { Piauí }\end{array}$ & 27 & 20.4588 \\
\hline II & Bajão and Costela de Vaca & 2 & 30.1397 \\
\hline III & BRS Novaera & 1 & - \\
\hline
\end{tabular}

Group I covered most of the genotypes, 27 in total: Rasga Letra, Cabeçudo, Pitiúba, Manteiga, Coruja, Canapu PE, Paulistinha, Epace 10, Maravilha, Miranda IPA 207, BRS Xiquexique, BRS Tumucumaque, BRS Guariba, Sempre Verde Verdadeiro, Bastião, Sempre Verde Salgueiro, Bastiãozinho, Patativa, Chico Modesto 2, Rouxinol, Esperança, Portalegre RN1, Canapuzinho, Safrinha 1, Pele de Moça, CNC 0434, and BR 10 Piauí. Group II comprised the genotypes Bajão and Costela de Vaca. The quantitative traits showed that both genotypes stood out from the others because they had a higher number of days to begin flowering, longer pod length, and higher weight of pods. Group III comprised only the genotype BRS Novaera, which presented quantitative traits quite different from the other genotypes, such as higher number of pods per peduncle, higher number of pods per plant, shorter pod length, lower pod weight, lower grain weight per pod, lower grain index, lower number of grains per pod, and lower productivity.

These three groups represented 90, 6.67, and $3.33 \%$ of the studied genotypes. The results confirm the assertion in the choice of descriptors, showing they were efficient to separate the assessed genotypes into distinct groups. Similarly, Bertini et al. (2009) used 13 descriptors in 16 cowpea accessions and verified the formation of nine distinct groups by Tocher Optimization method based on the Mahalanobis distance, noting an efficiency of descriptors in discriminating different accessions.

The longest mean distance found was between groups II and III (129.87), with the highest divergences between groups, which allows recommending the use of genotypes of these groups as parents in crosses, as they have excellent agronomic characteristics and could enable the emergence of better genetic combinations. The shortest mean distance was found between groups I and II (66.08), and therefore the crossing between genotypes of these groups is not indicated due to the low probability of superior genotypes arising in the segregating generations.

The UPGMA analysis of the 30 genotypes based on the generalized Mahalanobis distance $\left(\mathrm{D}^{2}\right)$ and cut-off using the Mojena method (1977) showed the formation of four distinct groups (Figure 1).

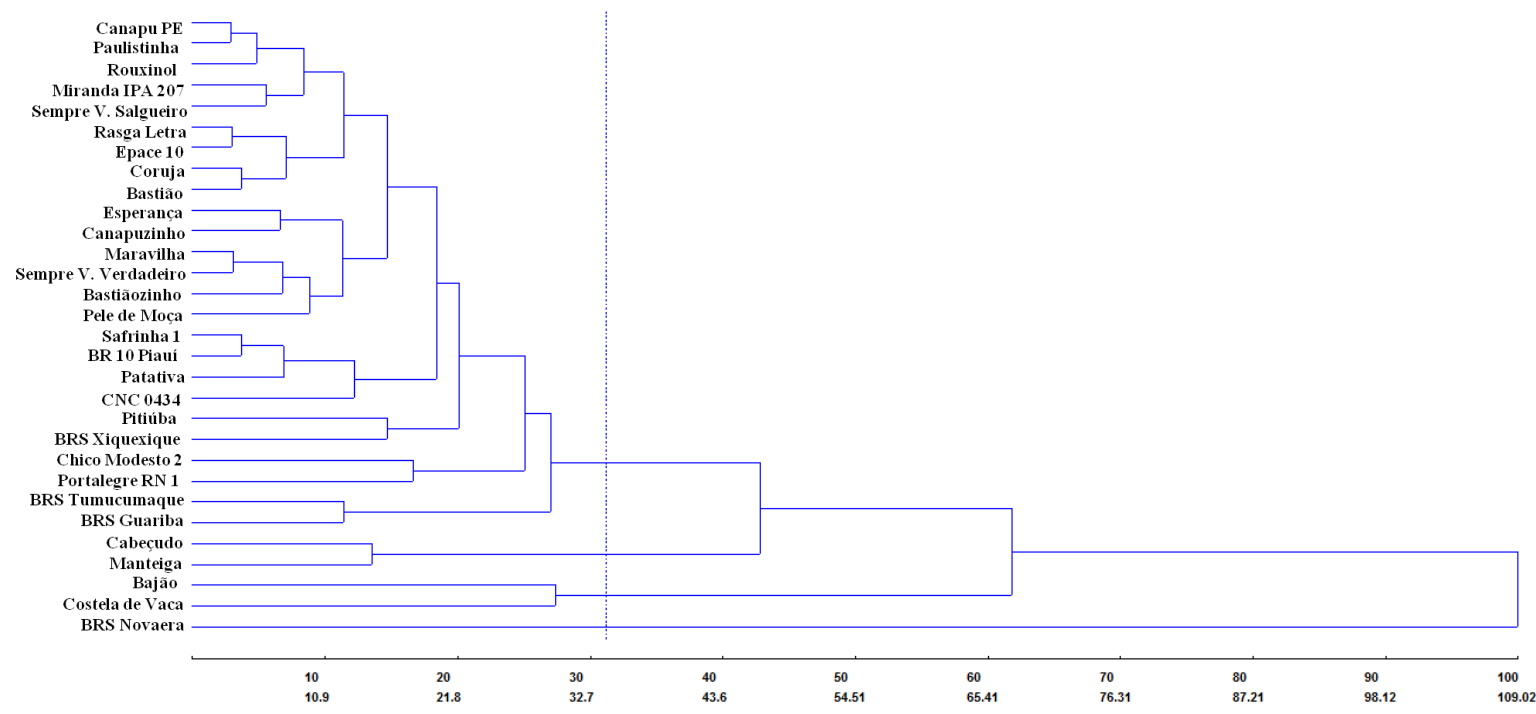

Figure 1. Dendrogram from the cluster analysis by UPGMA method based on Mahalanobis $D^{2}$ distances estimated from ten descriptors assessed in 30 cowpea genotypes. Goiana, PE, 2017. 
Group I comprised 25 genotypes: Rasga Letra, Pitiúba, Coruja, Canapu PE, Paulistinha, Epace 10, Maravilha, Miranda IPA 207, BRS Xiquexique, BRS Tumucumaque, BRS Guariba, Sempre Verde Verdadeiro, Bastião, Sempre Verde Salgueiro, Bastiãozinho, Patativa, Chico Modesto 2, Rouxinol, Esperança, Canapuzinho, Safrinha 1, Pele de Moça, Porta Alegre RN 1, CNC 0434, and BR 10 Piauí, corresponding to $83.33 \%$ of the accessions. Group II comprised the genotypes Cabeçudo and Manteiga, group III the genotypes Bajão and Costela de Vaca, and group IV only BRS Novaera, confirming this genotype as the most divergent among all since it is in an exclusive group, separated from the other groups by both methodologies.

The highest genetic divergences found based on the Mahalanobis distance were obtained between the pairs of genotypes BRS Novaera X Costela de Vaca $\left(D^{2}=164.30\right)$, BRS Novaera X Bajão $\left(D^{2}=\right.$ 155.01), and BRS Novaera $X$ Manteiga $\left(D^{2}=\right.$ 141.55). However, the shortest distances were found between the genotypes Canapu PE X Paulistinha $\left(\mathrm{D}^{2}\right.$ $=3.13)$, Rasga Letra X Epace $10\left(\mathrm{D}^{2}=3.26\right)$, and Maravilha X Sempre Verde Verdadeiro $\left(\mathrm{D}^{2}=3.35\right)$ (Data not shown)

The maximum $\mathrm{D}^{2}$ distance was observed mostly when the genotypes were combined with BRS Novaera, indicating it as the most divergent in the group of assessed genotypes. Despite not having high productivity, this genotype stood out for the trait number of pods per plant and hundred-grain weight, both directly related to productivity.

The most divergent pairs of genotype can be used in crosses, resulting in new gene combinations. Thus, considering the set of agronomic traits of production and genetic distance between genotypes, the recombination between the genotype Pitiúba, which presented medium precocity, good pod length, grain index, and number of grains per pod, and high productivity, coupled with its semi-erect habit, color and grain shape, characteristics that meet the wishes of producers and consumers, could be combined with the genotypes Cabeçudo, Manteiga, and Costela de Vaca, as they also have good agronomic traits, such as pod weight, grain weight per pod, number of grains per pod, hundred-grain weight, and high productivity, which may lead to new gene combinations favorable to the breeder.

The Singh (1981) method was used to obtain the relative contribution of traits, and those that contributed the most to the genetic diversity of the 30 genotypes were pod weight $(18.70 \%)$, beginning of flowering $(18.40 \%)$, pod length $(14.74 \%)$, and hundred-grain weight $(10.61 \%)$. These results indicate a genetic variability for these traits within the assessed populations. The traits that contributed least were the number of grains per pod $(2.75 \%)$ and grain index (3.29\%) (Table 6)

Table 6. Relative contribution of traits to the genetic divergence of Singh (1981) in 30 cowpea genotypes, Goiana, PE, 2017.

\begin{tabular}{cc}
\hline Variable & Value (\%) \\
Pod weight & 18.70 \\
Beginning of flowering & 18.40 \\
Pod length & 14.74 \\
Hundred-grain weight & 10.61 \\
Number of pods per plant & 10.18 \\
Grain productivity & 8.63 \\
Grain weight per pod & 7.14 \\
Number of pods per peduncle & 5.53 \\
Grain Index & 3.29 \\
Number of grains per pod & 2.75 \\
\hline
\end{tabular}

Several studies on genetic divergence in cowpea have shown differences in their results regarding the relative contribution of each trait. Bertini et al. (2009) assessed 16 accessions from BAG-UFC and found that the traits that most contributed to genetic divergence were pod length (69.04\%) and hundred-seed weight (19.94\%). Santos et al. (2014) assessed 20 genotypes, being nine strains and eleven commercial cultivars, and observed that five-pod grain weight $(43.2 \%)$ and hundred-grain weight $(28.8 \%)$ were the traits that contributed the most to genetic divergence.

\section{CONCLUSIONS}

Genetic divergence was observed among the assessed cowpea genotypes, allowing using the most divergent as parents to increase grain productivity gain.

The traits pod weight, beginning of flowering, pod length, hundred-grain weight, and the number of pods per plant contributed the most to discriminate the genetic divergence among the studied genotypes.

Crosses indicated to enable new gene combinations more favorable for cowpea breeding program are Pitiúba x Cabeçudo, Pitiúba x Manteiga, 
and Pitiúba $x$ Costela de Vaca, as they present the genotypes with the highest genetic divergences and have satisfactory agronomic traits regarding grain weight per pod, number of grains per pod, and grain yield per hectare.

\section{ACKNOWLEDGMENTS}

To the Agronomic Institute of Pernambuco (IPA) for providing seeds and all technical support; to the Federal Rural University of Pernambuco (UFRPE) and the Coordination for the Improvement of Higher Education Personnel (CAPES) for the granting of the scholarship.

\section{REFERENCES}

ALLARD, R. W. Principles of plant breeding. New York: John Wiley e Sons. 1960, p. 458.

ALMEIDA, W. S. et al. Identificação de genótipos de feijão-caupi tolerantes a salinidade avaliado por meio de método multivariado. Revista Ciência Rural, v. 41, n. 11, p. 1884-1889, 2011.

BARBIERI, R. L. et al. Divergência genética entre populações de cebola com base em marcadores morfológicos. Revista Ciência Rural, v. 35, n. 02, p. 303-308, 2005.

BARROSO NETO, A. M. et al. Variabilidade genética e seleção de progênies de feijão-caupi extraprecoces. Revista Caatinga, v. 30, n. 3, p. 698$707,2017$.

BASTOS, E. A. et al. Parâmetros fisiológicos e produtividade de grãos verdes do feijão-caupi sob déficit hídrico. Water Resources and Irrigation Management, v. 1, n. 1, p. 31-37, 2012.

BERTINI, C. H. C. M. et al. Divergência genética entre acessos de feijão-caupi do banco de germoplasma da UFC. Revista Ciência Agronômica, v. 40, n. 1, p. 99-105, 2009.

BERTINI, C. H. C. et al. Análise multivariada e índice de seleção na identificação de genótipos de feijão-caupi. Acta Scientiarum, v. 32, n. 4, p. 613$619,2010$.

BEZERRA, F. M. L. et al. Feijão caupi e déficit hídrico em suas fases fenológicas. Revista Ciência Agronômica, v. 34, n. 01, p. 5-10, 2003.

BEZERRA, A. A. C. et al. Morfologia e produção de grãos em linhagens modernas de feijão-caupi submetidas a diferentes densidades populacionais.
Revista de Biologia e Ciências da Terra, v. 8, n. 1, p. 85-92, 2008.

BEZERRA, A. K. P. et al. Rotação cultural feijão caupi/milho utilizando-se águas de salinidades diferentes. Revista Ciência Rural, v. 40, n. 5, p. 175 $-182,2010$.

BIODIVERSITY INTERNATIONAL. Descritores de Feijão-caupi (Vigna unguiculata (L.) Walp.), 2007. Disponível em: <http:// www.bioversityinternational.org/e-library/ publications/detail/descriptors-for-cowpea/>. Acesso em: 17 ago. 2018.

COMPANHIA

NACIONAL

$\mathrm{DE}$

ABASTECIMENTO - CONAB. Acompanhamento da safra brasileira: grãos, décimo levantamento, julho 2018. Brasília, Conab, v. 10, p. 1-145. Disponível em: <https://www.conab.gov.br/infoagro/safras/graos>. Acesso em: 18 ago. 2018.

CORREA, A. M. et al. Estimativa de parâmetros genéticos e correlações entre caracteres fenológicos e morfoagronômicos em feijão-caupi. Revista Ceres, v. 59, n. 1, p. 88-94, 2012.

CRUZ, C. D. Programa genes: Aplicativo Computacional em Genética e Estatística. Versão Windows - 2015. Viçosa: UFV, 2015.

EMPRESA BRASILEIRA DE PESQUISA AGROPECUÁRIA - EMBRAPA. Centro Nacional de Pesquisa de Solos (Rio de Janeiro, RJ). Manual de Métodos de Análise de solo. 2 ed. Rio de Janeiro, RJ: Embrapa Solos, p. 212, 1997.

FREIRE FILHO, F. R. et al. Feijão-caupi no Brasil: produção, melhoramento genético, avanços e desafios. Teresina, PI: Embrapa Meio Norte, 2011. $80 \mathrm{p}$.

LOPES, A. C. A. et al. Variabilidade entre caracteres agronômicos em caupi (Vigna unguiculata (L.) Walp.). Pesquisa Agropecuária Brasileira, v. 36, n. 3 , p. $515-520,2001$.

MAHALANOBIS, P. C. On the generalized distance in statistics. Proceedings of the National Institute of Science of India, v. 12, n. 1. p. 49-55, 1936.

MATOS FILHO, C. H. A. et al. Potencial produtivo de progênies de feijão-caupi com arquitetura ereta de planta. Revista Ciência Rural, v. 39, n. 2, p. 348354, 2009.

MILligAN, G. W.; COOPER, M. C. An examination of procedures for determining the number of clusters in a data set. Psychometrika, v. 50, n. 2, p. 159-179. 
MOJENA, R. Hierarchical grouping methods and stopping rules: an evaluation. The Computer Journal, v. 20, n. 4, p. 359-363, 1977.

OLIVEIRA, F. J. et al. Divergência genética entre cultivares de caupi. Pesquisa Agropecuária Brasileira, v. 38, n. 5, p. 605-611, 2003.

PASSOS, A. R. et al. Divergência genética em feijão -caupi. Revista Bragantia, v. 66, n. 04, p. 579-586, 2007.

RAO, A. V. et al. Genetic divergence among some brown planthopper resistant rice varieties. The Indian Journal of Genetic Plant Breeding, v. 41, n. 2, p. $179-185,1981$.

ROCHA, M. M. et al. Controle genético do comprimento do pedúnculo em feijão-caupi. Pesquisa Agropecuária Brasileira, v. 44, n. 3, p. 270-275, 2009.

SANTOS, J. A. S. et al. Desempenho agronômico e divergência genética entre genótipos de feijão-caupi cultivados no ecótono Cerrado/Pantanal. Revista Bragantia, v. 73, n. 4, p. 377-382, 2014.

SILVA, E. F. et al. Avaliação de cultivares de feijãocaupi irrigado para produção de grãos verdes em Serra Talhada - PE. Revista Caatinga, v. 26, n. 1, p. 21-26, 2013.

SINGH, D. The relative importance of characters affecting genetic divergence. Journal of Genetic and Plant Breeding, v. 41, n. 2, p. 237-245, 1981.

TEIXEIRA, I. R.; SILVA, G. C. et al. Desempenho agronômico e qualidade de sementes de cultivares de feijão-caupi na região do cerrado. Revista Ciência Agronômica, v. 41, n. 2, p. 300-307, 2010.

TORRES FILHO, J. et al. Divergência genética entre genótipos de feijão-caupi com base em caracteres associados com o mercado de vagens e grãos verdes. Revista Caatinga, v. 31, n. 1, p. 56-63, 2018.

XAVIER, G. R. et al. Variabilidade genética em acessos de caupi analisada por meio de marcadores RAPD. Pesquisa Agropecuária Brasileira, v. 40, n. 4, p. 353-359, 2005. 